\title{
Tingkat Kesejahteraan Rumah Tangga Petani Karet di Kecamatan Barong Tongkok Kabupaten Kutai Barat
}

\author{
Achmad Zaini ${ }^{1}$, Yulianus Pendi ${ }^{2}$, dan Juraemi ${ }^{2}$ \\ 1,2 Fakultas Pertanian, Universitas Mulawarman, Samarinda, Kalimantan Timur \\ 1Email: ach.zaini@gmail.com
}

\begin{abstract}
The purpose of this research were to know how much contribution of rubber farming income to household income and to know welfare le vel of rubber farmers. This research was conducted in Barong Tongkok Sub District, West Kutai Regency. The number of respondents taken was 40 farmers from 436 farmers based on stratified random methods. The results of the study showed that based on the results of observations for 40 respondents was obtained the production of rubber farming for one year was 178.485 $\mathrm{kg}$ with an average of $4,462,125 \mathrm{~kg} / \mathrm{respondent}$. The price of rubber product was IDR $6,000 / \mathrm{kg}$ so the revenue of rubber farming for one year of IDR 1,070,910,000, with average of revenue per respondent of IDR 26,772,750. Household total income was IDR 1,211,184,750 for one year with an average of IDR 30,279,618.75 per respondent. Rubber farming income more give the contribution to the household income total was $85.91 \%$, while the contribution of the income from non-rubber agriculture income was $6.27 \%$ and from non-agricultural income was $7.81 \%$. The welfare level of most rubber farming household was included in the decent living category of $65 \%$.
\end{abstract}

Keywords: Rubber, farming, income, contributions, welfare

\begin{abstract}
ABSTRAK
Tujuan penelitian ini adalah mengetahui seberapa besar kontribusi pendapatan usaha tani karet terhadap pendapatan rumah tangga serta tingkat kesejahteraan petani karet. Penelitian ini dilaksanakaan di Kecamatan Barong Tongkok Kabupaten Kutai Barat. Jumlah responden yang diambil sebanyak 40 orang dari 436 petani berdasarkan metode acak berstrata. Hasil penelitian menunjukan bahwa total produksi karet yang dihasilkan oleh seluruh petani yang menjadi responden adalah $178.485 \mathrm{~kg}$ dalam satu tahun dengan rata-rata $4.462,125 \mathrm{~kg}$ dan dengan harga jual $\mathrm{Rp} 6.000 / \mathrm{kg}$. Jumlah penerimaan yang diperoleh dalam satu tahun sebesar Rp 1.070.910.000, dengan ratarata per responden sebesar Rp 26.772.750 per tahunnya. Total pendapatan keluarga yang diperoleh sebesar $\mathrm{Rp} 1.211 .184 .750$ dengan rata-rata $\mathrm{Rp} 30.279 .618,75$. Kontribusi usahatani karet terhadap pendapatan rumah tangganya sebesar $85,91 \%$ terhadap total pendapatan rumahtangga, sedangkan untuk kontribusi pendapatan dari usaha pertanian non karet sebesar 6,27\% dan kontribusi pendapatan non pertanian sebesar 7,81\%. Berarti usaha tani karet ini sangat besar kontribusinya terhadap pendapatan rumah tangga. Tingkat kesejahteraan sebagian besar rumah tangga petani karet termasuk dalam kategori hidup layak $65 \%$.
\end{abstract}

Kata kunci: Karet, Pendapatan, Kontribusi, Kesejahteraan, Usahatani.

\section{Pendahuluan}

Pendapatan adalah salah satu indikator penting untuk melihat tingkat kesejahteraan masyarakat. Setiap orang berkeinginan untuk hidup sejahtera, untuk berbagai kriteria digunakan untuk mengukur kesejahteraan. Secara mikro kesejahteraan rumah tangga dapat didekati dengan hukum Engel, yang menyatakan pangsa pengeluaran makanan terhadap pengeluaran rumah tangga akan semakin berkurang dengan pendapatan yang meningkat. Lebih lanjut dalam keadaan harga barang dan selera masyarakat tetap maka peningkatan pendapatan menunjukkan peningkatan kesejahteraan (Boediono, 2002). 
Menurut Daniel (2002), menyatakan pendapatan adalah hasil bruto dikurangi dengan biaya-biaya yang dikeluarkan untuk usaha tani seperti bibit, pupuk, pestisida, biaya pengolahan tanah, upah menanam, upah pemeliharaan, biaya panen, sedangkan (Soedarsono, 2004), pendapatan yang diterima oleh produsen dan hasil produksi adalah penerimaan yang dikurangi dengan total biaya yang dikeluarkan selama proses produksi. Tinggi rendahnya pendapatan sangat berpengaruh dengan tingkat kesejahteraan masyarakat dan tingkat kemiskinan masyarakat.

Pendapatan petani merupakan ukuran penghasilan yang diterima oleh petani dari usahataninya. Dalam analisis usahatani, pendapatan petani digunakan sebagai indikator penting karena merupakan sumber utama dalam mencukupi kebutuhan hidup sehari-hari. Menurut Hernanto (2005), pendapatan merupakan suatu bentuk imbalan untuk jasa pengelolaan yang menggunakan lahan, tenaga kerja, dan modal yang dimiliki dalam berusahatani. Kesejahteraan petani akan lebih meningkat apabila pendapatan petani menjadi lebih besar dan apabila petani dapat menekan biaya yang dikeluarkan serta diimbangi dengan produksi yang tinggi dan harga yang baik. Pengaruh harga dan produktivitas yang berubah ubah mengakibatkan pendapatan petani juga ikut berubah pula.

Sejahtera mengandung pengertian aman sentosa, makmur, serta selamat, terlepas dari berbagai gangguan. Undang-Undang Nomor 11 Tahun 2009 tentang Kesejahteraan Sosial menyebutkan bahwa keadaan sejahtera, yaitu suatu tata kehidupan dan penghidupan sosial, baik material maupun spiritual, yang diliputi oleh rasa keselamatan, kesusilaan, dan ketentraman lahir batin. Sajogyo (1996) menjelaskan pengukuran kesejahteraan didasari atas kriteria garis kemiskinan. Kriteria tersebut meliputi rumah tangga paling miskin, rumah tangga miskin sekali, rumah tangga miskin, rumah tangga nyaris miskin, rumah tangga cukup, dan rumah tangga hidup layak. Salah satu indikator untuk mengukur tingkat kesejahteraan adalah pendapatan yang diperoleh masyarakat

Kabupaten Kutai Barat merupakan kawasan penghasil karet terutama pada Kecamatan Barong banyak masyarakatnya yang bertani karet untuk kebutuhan hidup, sehingga sebagian pendapatan petani tersebut berasal dari usaha tani karet. Pendapatan petani ada juga berasal dari usaha tani selain karet dan non-pertanian. Usahatani lainnya ini seperti peternakan dan lainnya, sedangkan non-pertanian antara lain tukang bangunan, karyawan swasta, serta pedagang makanan. Hal ini dilakukan petani agar pendapatan petani tidak hanya tergantung dari usahatani karet.

Usaha tani karet dan usaha lainya berkontribusi memberikan pemasukan dalam sejumlah pendapatan yang diterima oleh masing-masing keluarga petani. Bersumber dari berbagai usaha dapat dihitung total pendapatan yang diterima dari usaha tani karet terhadap pendapatan keluarga petani. Kontribusi usaha tani karet dapat diketahui dengan 
membandingkan pendapatan usahatani karet dengan total pendapatan rumah tangga petani keseluruhan. Usahatani karet akan turut menentukan besarnya pendapatan rumah tangga petani yang nantinya akan menentukan tinggi rendahnya tingkat kesejahteraan rumah tangga petani karet.

Kecamatan Barong Tongkok merupakan wilayah yang sebagian besar penduduknya sebagai petani terutama usahatani karet, namun sumber pendapatan penduduk Barong Tongkok ternyata tidak hanya usaha tani karet, tetapi juga dari usahatani lainya serta dari usaha non pertanian. Penelitian ini bertujuan untuk melihat berapa besar kontribusi pendapatan dari sumber usahatani karet, pertanian non karet dan usaha non pertanian lainnya. Disamping itu, dianggap penting dalam penelitian mengukur tingkat kesejahteraan rumah tangga petani karet.

\section{Metode Penelitian}

Penelitian ini dilaksanakan selama 3 bulan yaitu dari bulan November 2018 hingga Januari 2019. Lokasi penelitian di Kecamatan Barong Tongkok Kabupaten Kutai Barat. Pengambilan data pada penelitian ini meliputi data primer dan data sekunder. Data primer diperoleh melalui wawancara langsung kepada responden dengan menggunakan daftar pertanyaan (kuisioner) yang telah disusun sesuai dengan tujuan penelitian. Data sekunder diperoleh dari buku referensi yang terkait dengan penelitian, data dari instansi dan hasil penelitian yang dilakukan sebelumnya yang relevan dengan penelitian ini.

Pengambilan sampel dilakukan dengan metode acak dengan stratified random sampling karena populasi yang ada bersifat heterogen. Pada saat ini jumlah petani karet yang ada di Kecamatan Barong Tongkok Kabupaten Kutai Barat sebanyak 436 petani. Menurut Indriantoro dan Supomo (2002), pemilihan sampel dapat dilakukan dengan terlebih dahulu mengklasifikasikan suatu populasi kedalam sub-sub populasi berdasarkan jenis kelamin, industri, tahun angkatan, size perusahaan. Sampel kemudian dipilih dari sub populasi dengan metode acak sederhana atau metode sistematis.

Cara pemilihan sampel ini disebut dengan metode pemilihan sampel secara acak berdasarkan strata. Dasar yang digunakan untuk stratifikasi sub pupulasi dipertimbangkan aspek relevansinya dengan tujuan penelitian. Jumlah petani karet di Kecamatan Barong Tongkok sebanyak 436 petani dengan luas lahan karet keseluruhan 504 ha yang tergabung dalam 14 kelompok tani.

Arikunto (2002), penentuan sampel juga disesuaikan dengan kemampuan peneliti dari waktu, tenaga, dan dana. Serta luasnya wilayah pengamatan dari setiap subjek, karena hal ini menyangkut banyak sedikitnya data, besar kecilnya resiko yang di tanggung oleh 
peneliti. Maka peneliti menentapkan presisi sebesar $15 \%$ adapun cara pengambilan sampel menggunakan rumus sebagai berikut (Yamane dalam Rakmat, 2009):

$$
n=\frac{N}{N d^{2}+1}
$$

Keterangan:

$\mathrm{n}$ : Jumlah sampel

$\mathrm{N}$ : Jumlah Populasi

d : Batas toleransi kesalahan pengambilan sampel yang di gunakan (15\%)

Berdasarkan perumusan diatas jumlah sampel yang diperoleh adalah sebagai berikut :

$$
n=\frac{436}{436(0,15)^{2}+1}=40,33
$$

Sampel yang terpilih dari 436 petani adalah 40 petani (jumlahnya dibulatkan dari 40,33 petani). Berdasarkan jumlah sampel tersebut lalu di gunakan untuk menghitung sampel dalam masing masing strata (kelompok tani) yang digunakan untuk stratifikasi yaitu sebagai berikut:

Rumus untuk menghitung sampel dalam masing - masing strata adalah:

$$
n_{i}=\frac{n}{N} x N_{i}
$$

Keterangan :

$n_{i}:$ Jumlah sampel dalam strata ke-i

$\mathrm{N}$ : Jumlah Populasi

$\mathrm{n}$ : Jumlah sampel

$N_{i}$ : Jumlah populasi dalam strata ke-l

Tabel 1. Data Kelompok Tani dan Jumlah Tani

\begin{tabular}{clcc}
\hline No & Kelompok Tani & Jumlah Petani $\left(\mathbf{N}_{\mathbf{i}}\right)$ & \multicolumn{1}{c}{ Jumlah Sampel $\left(\mathbf{n}_{\mathbf{i}}\right)$} \\
\hline 1 & Jantur Mapan & 34 & $\mathrm{ni}=40 / 436 \times 34=3,12=3$ \\
2 & Karet Abadi & 38 & $\mathrm{ni}=40 / 436 \times 38=3,49=3$ \\
3 & Karya Tani & 40 & $\mathrm{ni}=40 / 436 \times 40=3,67=4$ \\
4 & Hasil Karya & 25 & $\mathrm{ni}=40 / 436 \times 25=2,29=2$ \\
5 & Ngeyan Jaya & 20 & $\mathrm{ni}=40 / 436 \times 20=1,83=2$ \\
6 & Tunas Muda & 37 & $\mathrm{ni}=40 / 436 \times 37=3.39=3$ \\
7 & Tunas Harapan & 21 & $\mathrm{ni}=40 / 436 \times 21=1.93=2$ \\
8 & Subur & 33 & $\mathrm{ni}=40 / 436 \times 33=3,03=3$ \\
9 & Makmur & 27 & $\mathrm{ni}=40 / 436 \times 27=2,48=2$ \\
10 & Pelita & 31 & $\mathrm{ni}=40 / 436 \times 31=2,84=2$ \\
11 & Karya Indah 1 & 38 & $\mathrm{ni}=40 / 436 \times 38=3,49=3$ \\
12 & Karya Indah 2 & 46 & $\mathrm{ni}=40 / 436 \times 46=4,22=4$ \\
13 & Sumber Usaha & 36 & $\mathrm{ni}=40 / 436 \times 36=3,30=3$ \\
14 & Sumber Usaha 2 & 10 & $\mathrm{ni}=40 / 436 \times 10=0,92=1$ \\
\hline
\end{tabular}

Setelah dilakukan perhitungan, jumlah sampel yang dilakukan sebesar 40 responden petani karet se-Kecamatan Barong Tongkok Kabupaten Kutai Barat. Jumlah Masing-Masing petani karet se-Kecamatan Barong Tongkok Kabupaten Kutai Barat pada Kelompok Tani Jantur Mapan sebanyak 3, Karet Abadi sebanyak 3, Karya Tani sebanyak 
ISSN 2354-7251 (print)

4, Hasil Karya sebanyak 2, Ngeyan Jaya sebanyak 2, Tunas Muda sebanyak 3, Tunas Harapan sebanyak, 2, Subur sebanyak 3, Makmur sebanyak 2, Pelita sebanyak 3, Karya Indah 1 sebanyak 3, Karya Indah 2 sebanyak 4, Sumber Usaha sebanyak 3, Sumber Usaha 2 sebanyak 1.

Analisis data yang digunakan yaitu analisis biaya, analisis penerimaan total, analisis pendapatan total, analisis kontribusi pendapatan usahatani karet, analisis pendapatan rumah tangga, analisis tingkat kesejahteraan, sebagai berikut:

\section{Biaya}

Pendapatan yang di peroleh di sajikan dalam bentuk tabel, kemudian di analisis dibahas dan ditarik kesimpulan (Soekartawi, 2010). Total biaya adalah biaya tetap ditambah biaya variabel untuk mengetahui total biaya yang dikeluarkan selama proses produksi dapat di rumuskan sebagai berikut :

$$
\mathrm{TC}=\mathrm{TFC}+\mathrm{TVC}
$$

Keterangan:

TC : Biaya total / Total Cost

TFC : Biaya tetap / Total fixed cost

TVC : Biaya variable / Total variable cost

\section{Penerimaan}

Untuk mengetahui besarnya penerimaan usaha tani karet dapat dilakukan dengan analisis yang dikemukakan oleh (Soekartawi, 2010) sebagai berikut :

$$
\mathrm{TR}=\mathrm{P} . \mathrm{Q}
$$

Keterangan :

TR : Penerimaan Total / Total revenue (Rp)

P : : Harga / Price $(\mathrm{Rp} / \mathrm{Kg})$

Q : Jumlah Barang / Quantity (mt)

\section{Pendapatan Usahatani Karet}

Menurut Soekartawi (2010), pendapatan total diperoleh dari total penerimaan yang di kurangi dengan total produksi dalam masa produksi. Secara sistematis pendapatan usaha tani dapat dihitung menggunakan rumus sebagai berikut:

$$
\mathrm{I}=\mathrm{TR}-\mathrm{TC}
$$

Keterangan :

I : Pendapatan

TR : Total Penerimaan

TC : Total biaya

\section{Kontribusi Pendapatan Usaha Tani Karet}

Mengetahui besarnya kontribusi pendapatan usaha tani terhadap pendapatan petani digunakan rumus sebagai berikut:

$$
\text { K usaha tani karet }=\frac{\sum \text { pendapatan usahatani karet }}{\sum \text { seluruh pendapatan rumah tangga petani }} \times 100 \%
$$
Keterangan : 
$\mathrm{K}=$ Kontribusi

\section{Pendapatan Rumah Tangga}

Untuk menghitung total pendapatan rumah tangga petani adalah dengan menjumlahkan semua pendapatan yang diperoleh dari usahatani karet, pertanian lainnya dan pendapatan dari non pertanian, dengan rumus sebagai berikut;

$$
\text { TPRT }=\text { UTK }+ \text { UNK + UNP }
$$

Keterangan:

TPRT : Total pendapatan rumah tangga (Rp/tahun)

UTK : Usaha tani karet (Rp/tahun)

UNK : Usaha tani non karet (Rp/tahun)

UNP : Usaha non pertanian (Rp/tahun)

\section{Tingkat Kesejahteraan}

Sebagai teknis analisis data untuk perbandingan petani perkapita per tahun guna mengetahui tingkat kesejahteraan maka digunakan standar garis kemiskinan (poverty line) yang digagas oleh Sajogyo (1996) dimana pendapatan per kapita per tahun yang dihitung dalam setara beras yaitu masing-masing:

1. Rumah tangga paling miskin $<180 \mathrm{~kg} / \mathrm{kapita} /$ tahun.

2. Rumah tangga miskin sekali $181-240 \mathrm{~kg} / \mathrm{kapita} / \mathrm{tahun}$.

3. Rumah tangga miskin $241-320 \mathrm{~kg} / \mathrm{kapita} / \mathrm{tahun}$.

4. Rumah tangga nyaris miskin $321-480 \mathrm{~kg} / \mathrm{kapita} / \mathrm{tahun}$.

5. Rumah tangga cukup 481-960 kg/kapita/tahun.

6. Rumah tangga hidup layak $>960 \mathrm{~kg} / \mathrm{kapita} / \mathrm{tahun}$.

\section{Hasil dan Pembahasan}

\section{Biaya Produksi Usaha Tani Karet}

Biaya produksi adalah biaya yang dikeluarkan untuk seluruh faktor produksi yang digunakan dalam kegiatan usahatani. Biaya produksi yang diperhitungkan dalam usaha tani ini terdiri dari biaya variabel dan biaya tetap. Total biaya produksi yang dikeluarkan oleh 40 responden petani karet adalah $\mathrm{Rp} 30.325 .250 /$ tahun. dengan biaya rata-rata sebesar $\mathrm{Rp}$ 758.131,25/responden/tahun.

Biaya variabel

Biaya variabel (biaya tidak tetap) adalah biaya yang berubah-ubah tergantung luas dan kebutuhan lahan serta berpengaruh terhadap jumlah produksi. Biaya ini meliputi biaya benih, biaya pupuk, biaya pestisida, dan biaya tenaga kerja.

1. Biaya benih

Petani Karet di Kecamatan Barong Tongkok Kabupaten Kutai Barat mengunakan benih karet GT 1, dan mendapatakan benih karet sendiri dari pemerintah kabupaten yang memberikan benih itu berupa bantun berupa program PRPTE untuk petani. Sebagian 
petani juga mengambil benih karet dari teman tanpa biaya sedikitpun. Pada penelitian ini biaya benih tidak diperhitungkan karena biaya ini dikeluarkan pada saat awal tanam.

\section{Biaya pupuk}

Petani karet di Kecamatan Barong Tongkok Kabupaten Kutai Barat mengunakan 3 jenis pupuk yaitu Urea, SP-36 dan KCl. Harga pupuk untuk urea Rp 1.800/kg. jumlah pupuk urea yg digunakan oleh 40 responden sebesar $3.630 \mathrm{~kg}$ dengan rata-rata 90,75 kg, sedangkan untuk pupuk SP-36 harga Rp 3.000/kg, jumlah penggunaan pupuk SP-36 untuk 40 responden sebesar $1.765 \mathrm{~kg}$ dengan rata-rata $44,125 \mathrm{~kg}$, sedangkan untuk pupuk $\mathrm{KCl}$ harga $\mathrm{Rp} 10.000 / \mathrm{kg}$, jumlah penggunaan pupuk $\mathrm{KCl}$ untuk 40 responden sebesar $1.185 \mathrm{~kg}$ dengan rata-rata $29.265 \mathrm{~kg}$.

3. Biaya pestisida

Pestisida yang digunakan oleh responden yaitu roundup dan hanya sebagian responden yang mengunakan pestisida ini. Jumlah biaya yang dikeluarkan oleh 40 responden adalah sebesar $\mathrm{Rp}$ 1.040.000/tahun dengan rata-rata $\mathrm{Rp}$ 26.000/responden/tahun.

\section{Biaya tenaga kerja}

Biaya tenaga kerja berhubungan dengan kegiatan produksi dan pemeliharaan usaha tani karet di Kecamatan Barong Tongkok Kabupaten Kutai Barat. Kegiatan ini meliputi pengolahan lahan, penanaman, pemeliharaan dan panen. Pada lokasi penelitian tingkat upah untuk satu tenaga kerja tergantung dari jenis pekerjaan yang dilakukan. Untuk pengolahan lahan sebesar Rp 100.000, sedangkan untuk penanaman sebesar $\mathrm{Rp} 50.000$. Biaya pemeliharaan sebesar $R p 50.000$, sedangkan untuk panen sebesar $R p 100.000$. Jumlah biaya tenaga kerja yang dikeluarkan oleh 40 responden sebesar $\mathrm{Rp}$ 3.356.250 dengan rata-rata $\mathrm{Rp} 83.906,25$.

Biaya tetap

Biaya tetap adalah biaya yang dikeluarkan akan selalu tetap, tidak terpengaruh dan berpengaruh terhadap jumlah produksi. Komponen biaya tetap diantaranya biaya penyusutan alat. Alat yang digunakan dalam usaha tani karet adalah parang dan pisau sadap. Biaya penyusutan yang dikeluarkan oleh 40 responden adalah $R p$ 2.250.000/tahun dengan rata-rata $\mathrm{Rp}$ 56.250/responden/tahun.

\section{Produksi dan Penerimaan}

Berdasarkan hasil wawancara di lapangan dan perhitungan yang dilakukan oleh peneliti diketahui bahwa untuk hasil produksi usaha tani karet oleh setiap responden berbeda-beda dengan demikian maka penerimaan, biaya dan pendapatan yag diperoleh pun berbeda-beda setiap responden. 
Tabel 2. Rincian Total produksi, Penerimaan, Pendapatan dari 40 Responden Usaha Tani Karet

\begin{tabular}{lcccc}
\hline Keterangan & $\begin{array}{c}\text { Produksi } \\
(\mathbf{K g})\end{array}$ & $\begin{array}{c}\text { Penerimaan } \\
\text { (Rp/tahun) }\end{array}$ & $\begin{array}{c}\text { Biaya } \\
\text { Produksi } \\
\text { (Rp/tahun) }\end{array}$ & $\begin{array}{c}\text { Pendapatan } \\
\text { (Rp/tahun) }\end{array}$ \\
\hline Total & 178.485 & 1.070 .910 .000 & 30.325 .250 & 140.584 .750 \\
\hline Rata-Rata per responden & $4.462,125$ & 26.772 .750 & $758.131,25$ & $26.014 .618,75$ \\
\hline Sumber data primer diolah 2019. & & & &
\end{tabular}

Produksi adalah hasil yang diperoleh dalam masa panen selama satu tahun. Berdasarkan hasil penelitian terhadap 40 orang responden diperoleh hasil produksi karet sebesar 178.485 kg/tahun dengan rata-rata 4462 kg/responden/tahun. Penerimaan merupakan hasil kali dari produksi dengan harga jual dari produksi tersebut. Harga jual di lokasi penelitian yaitu Rp $6.000 / \mathrm{kg}$. Jumlah penerimaan yang diperoleh dari 40 petani karet sebesar Rp 1.070.910/tahun dengan rata-rata $\mathrm{Rp} 26.772,750 /$ responden/tahun. Pendapatan responden dalam penelitian ini didapat dari selisih antara total penerimaan dan total biaya produksi yang telah dikeluarkan selama satu tahun. Jumlah penerimaan yang diterima dari 40 responden petani karet sebesar $\mathrm{Rp}$ 1.070.910.000/tahun, dan jumlah biaya produksi Rp 30.325.250/tahun, maka pendapatan total dari 40 responden sebesar Rp 1.040.548.750/tahun.

\section{Pendapatan Usahatani Non Karet}

Sumber-sumber pendapatan usahatani non karet yang diusahakan oleh responden yang ada di Kecamatan Barong Tongkok Kabupaten Kutai Barat dilihat pada Tabel 3.

Tabel 3. Total Pendapatan dan Rata-Rata dari 40 Responden Usahatani Non Karet

\begin{tabular}{llcc}
\hline No & Usahatani & Total Pendapatan (Rp/tahun) & Rata-Rata (Rp/tahun) \\
\hline 1 & Ternak ayam & $35.000 .000,00$ & $7.000 .000,00$ \\
2 & Ternak babi & $27.000 .000,00$ & $5.400 .000,00$ \\
3 & Kacang panjang & $8.000 .000,00$ & $4.000 .000,00$ \\
4 & Jagung & $6.000 .000,00$ & $6.000 .000,00$ \\
\hline
\end{tabular}

Sumber data diolah 2019

Jumlah responden yang berternak ayam hanya 5 orang dengan total pendapatan sebesar Rp 35.000.000 dengan rata-rata sebesar Rp 7.000.000. Jumlah responden yang berternak babi hanya 5 orang dengan total pendapatan sebesar Rp 27.000.000 dengan rata-rata sebesar Rp 5.400.000. Jumlah responden yang berternak babi hanya 2 orang dengan total pendapatan sebesar Rp 8.000.000 dengan rata-rata sebesar Rp 4.000.000. Jumlah responden yang berternak babi hanya 1 orang dengan total pendapatan sebesar Rp 6.000.000 dengan rata-rata sebesar Rp 6.000.000.

\section{Pendapatan Usaha Non Pertanian}

Sumber-sumber pendapatan diluar pertanian yang diusahakan oleh responden di Kecamatan Barong Tongkok Kabupaten Kutai Barat adalah warung dan jasa tukang bangunan. Tabel 4 menunjukkan total pendapatan dari beberapa responden yang memiliki usaha non pertanian. Pedagang atau membuka usaha warung yang menjual berbagai jenis makanan dan minuman ringan merupakan salah satu sumber pendapatan responden. Terdapat 5 orang responden sebagai penjual/warung dengan total pendapatan selama 
ISSN 2354-7251 (print)

setahun sebesar Rp 73.600.000/ tahun dengan rata-rata pendapatan Rp 14.720.000/ responden/ tahun. Terdapat 4 orang responden yang juga berprofesi sebagai tukang bangunan. Pendapatan dari 4 orang yang bekerja sebagai tukang bangunan tersebut $\mathrm{Rp}$ 21.000.000/tahun dengan rata-rata pendapatan Rp 5.250.000/responden/tahun.

Tabel 4. Total Pendapatan Responden Non Usaha Tani.

\begin{tabular}{clcc}
\hline No. & Jenis Pekerjaan & Total Pendapatan(Rp/tahun) & Rata-Rata Pendapatan(Rp/tahun) \\
\hline 1 & Warung & $73.600 .000,00$ & $14.720 .000,00$ \\
2 & Tukang Bangunan & $21.000 .000,00$ & $5.250 .000,00$ \\
\hline Jumlah & $94.600 .000,00$ & $19.970 .000,00$ \\
\hline \multicolumn{2}{l}{ Sumber data primer diolah 2019} &
\end{tabular}

\section{Total Pendapatan Keluarga}

Total Pendapatan keluarga adalah jumlah keseluruhan pendapatan responden baik dari usahatani karet maupun non pertanian. Setelah dilakukan perhitungan maka diperoleh hasil untuk pendapatan usaha tani karet sebesar Rp 1.040.584.750 untuk non karet Rp 76.000.000, dan untuk non pertanian sebesar $\mathrm{Rp} 94.600 .000$, maka diperoleh untuk total pendapatan keluarga sebesar $\mathrm{Rp} 1.211 .184 .750$.

\section{Kontribusi Usaha Tani Karet}

Berdasarkan hasil penelitian yang telah dilakukan pada petani karet di Kecamatan Barong Tongkok Kabupaten Kutai Barat diperoleh hasil bahwa usaha tani karet memiliki kontribusi yang sangat besar terhadap total pendapatan keluarga yaitu sebesar $85,91 \%$. Hal ini dikarenakan petani menjadikan usaha tani karet menjadi usaha tani utama mereka.

Tabel 5. Kontribusi Usaha Tani Karet Terhadap Pendapatan Keluarga

\begin{tabular}{cccc}
\hline No & Kegiatan Usaha & Jumlah ( Rp/Thn ) & Persentase (\%) \\
\hline 1 & Tanaman Karet & 1.040 .584 .750 & 85,91 \\
2 & Non Karet & 76.000 .000 & 6,27 \\
3 & Non Pertanian & 94.600 .000 & 7,81 \\
\hline & Jumlah & 1.211 .184 .750 & 100
\end{tabular}

Sumber: Data primer diolah 2019.

\section{Tingkat Kesejahteraan Rumah Tangga}

Untuk mencari jumlah konsumsi beras/kapita/tahun dapat digunakan rumus sebagai berikut:

$$
\text { Konsumsi }=\frac{\text { Pendapatan rumah tangga/tahun }}{\frac{\text { hargaberas }}{\text { jumlahtanggungan }}}
$$

Dalam penelitian ini diketahui bahwa total konsumsi beras dari 40 orang petani karet adalah sebesar $53.171 \mathrm{~kg} /$ tahun dengan rata-rata konsumsi 1.329 kg/kapita/tahun. Rincian konsumsi beras dapat dilihat pada Tabel 6.

Tabel 6. Rincian Konsumsi Beras Petani Karet

\begin{tabular}{ccccc}
\hline No & $\begin{array}{c}\text { Jumlah konsumsi } \\
\text { (kg/orang) }\end{array}$ & $\begin{array}{c}\text { Jumlah responden } \\
\text { (orang) }\end{array}$ & $\begin{array}{c}\text { Persen } \\
\text { (\%) }\end{array}$ & Kategori \\
\hline 1 & $<180$ & - & - & Paling miskin \\
2 & $181-240$ & - & - & Miskin sekali \\
3 & $241-320$ & - & - & Miskin \\
4 & $321-480$ & 1 & 2,5 & Nyaris miskin \\
5 & $481-960$ & 13 & 32,5 & Berkecukupan \\
6 & $>960$ & 26 & 65 & Hidup layak \\
\hline & Jumlah & 40 & $100 \%$ & \\
\hline
\end{tabular}


Berdasarkan Tabel 6 dapat diketahui bahwa petani yang jumlah konsumsi beras dibawah $180 \mathrm{~kg}$, antara $181-240 \mathrm{~kg}$, dan antara 241-320 kg tidak ada, dengan kata lain bahwa tidak ada petani paling miskin, miskin sekali dan yang miskin, sedangkan untuk petani dengan konsumsi 321-480 kg berjumlah 1 orang yang dalam artian termasuk dalam kategori nyaris miskin. Petani yang jumlah konsumsinya 481-960 kg berjumlah 13 orang yang artinya masuk dalam kategori berkecukupan. Petani dengan konsumsi diatas $960 \mathrm{~kg}$ berjumlah 26 orang maka petani tersebut masuk dalam kategori hidup layak.

Besar kecilnya pendapatan usaha tani karet yang diterima oleh petani dipengaruhi oleh luas lahan dan harga jual, jika luas lahan yang ditanami karet besar maka banyak produksi juga meningkat dan pendapatan juga semakin besar. Pada penelitian ini jumlah luas lahan petani karet setiap responden hanya berkisar 1-4 ha. Begitu pula dengan harga jual, dengan besarnya harga jual karet maka pendapatan karet juga akan meningkat, harga jual karet terhadap petani dari tengkulak selalu berubah-ubah dari Rp 6.000 hingga $\mathrm{Rp}$ 13.000 ini juga dipengaruhi harga karet dunia dan dampak harga pasok yang jauh dari petani - tengkulak - pabrik. Pada penelitian ini harga yang diperoleh petani sebesar Rp $60.00 / \mathrm{kg}$. Jika harga karet dunia meningkat dan pabrik dekat maka harga dapat dikontrol maka harga juga akan naik secara tiba-tiba dari tengkulak maka tidak menutup kemungkinan harga karet akan meningkat.

Setelah melakukan perhitungan maka total produksi karet yang didapat oleh responden sebesar $178.485 \mathrm{~kg} /$ tahun dengan rata-rata $4.462,125 / \mathrm{kg} / \mathrm{responden} /$ tahun maka peneriman yang diterima oleh 40 responden dalam penelitian ini sebesar $\mathrm{Rp}$ 1.070.910.000/tahun dengan rata-rata $\mathrm{Rp} 26.772 .250$ /responden/tahun maka diketahui besar pendapatan responden petani karet sebesar Rp1.040.584.750/tahun dengan rata-

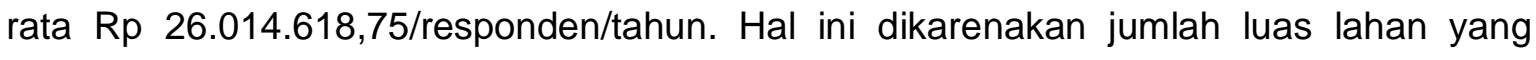
ditanami oleh setiap responden tidaklah begitu luas, sedangkan biaya produksi yang tinggi dan harga jual ditingkat petani ke tengkulak yang rendah sehingga menyebabkan pendapatan yang diperoleh dari petani usaha karet kecil, sedangkan pendapatan rumah tangga petani diperoleh dengan cara menjumlahkan semua usaha yang diterima petani baik dari usaha tani karet maupun non pertanian. Masing-masing responden memiliki jumlah pendapatan yang berbeda-beda, dikarenakan bahwa sumber pendapatan yang dimiliki untuk setiap responden berbeda. Sebagian besar responden dalam penelitian ini hanya memperoleh pendapatan dengan cara bertani, setelah melakukan perhitungan maka dapat diperoleh total pendaptan responden dari usaha tani baik dari karet maupun non karet dan non pertanian adalah sebesar Rp 1.211.184.750/tahun dengan rata-rata $\mathrm{Rp}$ 30.279.618,75/responden/tahun, maka dengan ini dapat diketahui kontribusi usaha tani karet terhadap pendapatan keluarga sebesar $85,91 \%$, kontribusi ini sangat besar sebab petani rata-rata petani yang bertani karet menjadikan usaha tani ini sebagai usaha utama. 
Untuk mengukur tingkat kesejahteraan rumah tangga ada beberapa macam cara, salah satunya dengan melihat dari pendapatan yang didapat kemudian dikalikan dengan harga beras saat itu. Pada penelitian ini untuk petani karet di Kecamatan Barong Tongkok Kabupaten Kutai Barat, diperoleh bahwa jumlah konsumsi beras responden dibawah 180 $\mathrm{kg}$ tidak ada atau dapat disimpulkan bahwa petani yang masuk dalam kategori paling miskin tidak ada, dan untuk petani yang jumlah konsumsi berasnya 181-240 kg juga tidak ada, dengan kata lain bahwa tidak ada petani yang masuk dalam kategori miskin sekali. Untuk petani yang jumlah konsumsinya $241-320 \mathrm{~kg}$ juga tidak ada, dengan kata lain bahwa tidak ada petani yang miskin, sedangkan untuk petani dengan konsumsi 321-480 kg berjumlah 1 orang yang dalam artian termasuk dalam kategori nyaris miskin. Petani yang jumlah konsumsinya 481-960 kg berjumlah 13 orang yang artinya masuk dalam kategori berkecukupan, dan untuk petani dengan konsumsi diatas $960 \mathrm{~kg}$ berjumlah 26 orang maka petani tersebut masuk dalam kategori hidup layak.

\section{Kesimpulan}

Berdasarkan analisis data dan pembahasan dapat ditarik kesimpulan bahwa total pendapatan petani dari komoditi karet di Kecamatan Barong Tongkok Kabupaten Kutai Barat adalah sebesar $\mathrm{Rp}$ 1.040.584.750/tahun, dengan rata-rata $\mathrm{Rp}$ 26.014.618,75/responden/tahun. Untuk pendapatan non karet sebesar $\mathrm{Rp}$ 76.000.000/tahun dengan rata-rata $\mathrm{Rp}$ 1.900.000/responden/tahun, dan untuk pendapatan usaha non pertanian sebesar $\mathrm{Rp}$ 94.600.000/tahun dengan pendapatan rata-rata $\mathrm{Rp}$ 10.511.111,11/petani/tahun. Kontribusi pendapatan usahatani karet terhadap pendapatan keluarga di Kecamatan Barong Tongkok Kabupaten Kutai Barat sebesar 85,91 \% , dari non karet sebesar 6,27\% dan dari usaha non pertanian sebesar 7,81\%. Tingkat Kesejahteraan petani karet di Kecamatan Barong Tongkok Kabupaten Kutai Barat yaitu petani yang masuk dalam kategori nyaris miskin sebesar $2,5 \%$ dan untuk kategori berkecukupan sebesar $32,5 \%$, sedangkan untuk kategori hidup layak sebebesar $65 \%$.

\section{Daftar Pustaka}

Arikunto, S. (2002). Metodologi Penelitian Suatu Pendekatan Proposal. Jakarta: Rineka Cipta.

Boediono. (2002). Ekonomi Mikro Seri Sinopsis Pengantar Ilmu Ekonomi No 1. Yogyakarta: BPFE.

Daniel, M. (2002). Pengantar Ekonomi Pertanian. Jakarta: Bumi Aksara.

Hernanto. (1991). Ilmu Usaha Tani. Jakarta: Penebar Swadaya.

Indriantoro, N., \& Supomo, B. (2002). Metode Penelitian Bisnis. Yogyakarta: BPFE.

Rakhmat, J. (2009). Metode Penelitian Komunikasi. Bandung: Remaja Rosdakarya. 
Sajogyo. (1996). Garis Kemiskinan dan Kebutuhan Minimum Pangan. Aditya Media.

Soedarsono. (2004). Pengantar Ekonomi Mikro. Jakarta: LP3Es.

Soekartawi. (2010). Agribisnis: Teori Dan Aplikasinya. Jakarta: Raja Grafindo Persada. 